\title{
KLASIFIKASI DATA PRODUK MEBEL ANEKA JAYA MENGGUNAKAN METODE K-NEAREST NEIGHBOR BERBASIS WEB
}

\author{
Ferdian Maulana, Mira Orisa, Hani Zulfia Zahro' \\ Program Studi Teknik Informatika S1, Fakultas Teknologi Industri \\ Institut Teknologi Nasional Malang, Jalan Raya Karanglo km 2 Malang, Indonesia \\ ferdianmaulana1999@gmail.com
}

\begin{abstract}
ABSTRAK
Toko Aneka Jaya merupakan toko mebel yang memiliki berbagai macam barang rumah tangga mulai dari kursi, meja, kasur dan lemari. Berdiri pada tahun 2009 dan telah berjalan selama 12 tahun. Toko ini memiliki permasalahan terkait pengklasifikasian data produk baru. Pada proses penelitian ini, dibuatlah sebuah sistem untuk mengklasifikasi data produk mebel untuk memudahkan pemilik toko mebel dalam mengklasifikasikan data produk mebel baru dengan menggunakan metode K-Nearest Neighbor (K-NN). Kriteria yang digunakan pada sistem ini adalah Nilai Panjang, Nilai Lebar, Nilai Tinggi, dan Nilai Harga. Website pada penelitian ini diimplementasikan dan dirancang dengan menggunakan bahasa pemograman PHP (Hypertext Preprocessor), dan Database menggunakan MySQL. Dari hasil pengujian website yang telah dibuat dengan metode K-Nearest Neighbor dapat ditarik kesimpulan bahwa hasil pengujian metode menggunakan confussion matrix menghasilkan nilai accuracy sebesar 90\% dari data prediksi menggunakan data di tahun 2019 dibandingkan dengan data real di tahun 2020 dan 80\% dari data prediksi menggunakan data di tahun 2020 dibandingkan dengan data real di tahun 2021 dan berhasil membantu dalam mengklasifikasikan data produk mebel baru. Perhitungan algoritma ini dilakukan menggunakan metode Euclidean Distance. Pengujian dilakukan pada website dengan menggunakan 2 browser yang berbeda, semua tampilan dan fungsi aplikasi dapat berjalan 100\% pada 2 browser yaitu, Opera versi 76.0.4017.177 dan Google Chrome versi 91.0.4472.106 pada Windows 10. Dengan adanya website ini diharapkan pemilik toko mebel dapat melakukan klasifikasi terhadap data produk mebel yang baru.
\end{abstract}

Kata Kunci : Klasifikasi, Mebel, K-Nearest Neighbor

\section{PENDAHULUAN}

Mebel merupakan perabot rumah tangga yang digunakan dalam kehidupan sehari-hari. Istilah lain yang digunakan adalah Furniture. Kata "furniture" berasal dari bahasa Prancis yaitu "fourniture" (152030 Masehi). Mebel atau Furniture adalah perlengkapan rumah yang mencakup semua barang seperti kursi, meja, dan lemari. Mebel berasal dari kata movable, yang artinya bisa bergerak. Pada zaman dahulu meja kursi dan lemari relatif mudah digerakkan dari batu besar, tembok, dan atap. Sedangkan kata furniture berasal dari bahasa Prancis fourniture (1520-30 Masehi). Fourniture mempunyai asal kata fournir yang artinya furnish atau perabot rumah atau ruangan. Walaupun mebel dan furniture punya arti yang beda, tetapi yang ditunjuk sama yaitu meja, kursi, lemari, dan seterusnya. Mebel bisa terbuat dari bahan dasar plastik, logam, bambu, kayu dan lain sebagainya. Mebel untuk produk artistik biasanya terbuat dari bahan dasar kayu pilihan dengan tekstur dan warna menarik yang dikerjakan dengan penyelesaian akhir yang halus. (Desi Karmila, 2019).

Toko Aneka Jaya merupakan toko mebel yang memiliki berbagai macam barang rumah tangga mulai dari kursi, meja, kasur dan lemari. Berdiri pada tahun 2009 dan telah berjalan selama 12 tahun. Toko Aneka Jaya memiliki kesulitan dalam mengklasifikasian data produk baru untuk menentukan apakah produk mebel baru tersebut termasuk diminati atau kurang diminati.

Berdasarkan permasalahan yang telah diuraikan diatas, maka dibuat sebuah sistem klasifikasi data produk mebel aneka jaya menggunakan metode KNearest Neighbor berbasis web.

\section{TINJAUAN PUSTAKA}

\subsection{Penelitian Terdahulu}

Menurut Kafil (2019) pada penelitian dengan judul "Penerapan Metode K-Nearest Neighbors Untuk Klasifikasi Penjualan Berbasis Web Pada Boutiq Dealove Bondowoso". Tujuan penelitian ini yaitu untuk menentukan jumlah stok mana saja yang harus dijual lebih sedikit dan lebih banyak peminatnya agar stok butik seimbang dan tidak sampai kehabisan.

Pungky (2019) pada penelitian dengan judul "Penerapan Metode KNN Untuk Memklasifikasi Hasil Pertanian Di Kabupaten Malang". Tujuan penelitian ini yaitu untuk dapat memfokuskan bantuan pertanian di daerah mana yang perlu ditingkatkan kualitas dan kuantitas panennya dan pemasok dapat mencari daerah baru untuk memasok barang.

Andrea (2019) pada penelitian berjudul "Analisis Kualitas Hasil Panen Tembakau Menggunakan K-Nearest Neighbors Berbasis Web". Tujuan penelitian ini yaitu untuk menganalisis 
kelayakan kualitas tembakau apakah layak atau tidak. Adapun persamaan dari penelitian yaitu sama-sama menggunakan metode K-Nearest Neighbors untuk mendapatkan hasil.

Farhan (2018) pada penelitian dengan judul "Penerapan Metode K-Nearest Neighbors Untuk Memklasifikasi Predikat Prestasi Akademik Santri Taman Pendidikan Al-Qur'an (TPQ) Al-Izzah Sidoarjo". Tujuan penelitian ini yaitu untuk mengetahui penerapan algoritma knn untuk membantu mengetahui prestasi akademik santri yang prestasinya sedang naik ataupun turun dengan cepat dan akurat.

Taftyani, Yusuf (2017) pada penelitian dengan judul "Metode Klasifikasi Mutu Jambu Biji Menggunakan knn Berdasarkan Fitur Warna Dan Tekstur". Tujuan penelitian ini yaitu untuk mengetahui kondisi buah jambu biji apakah buah tersebut tergores, busuk dan terkena benturan. Persamaan dari penelitian ini yaitu sama-sama menggunakan metode knn untuk mendapatkan hasil.

\subsection{Data Mining}

Data Mining merupakan langkah analisis terhadap suatu proses penemuan pada pengetahuan didalam basis data atau knowledge discovery in database disingkat KDD. Pengetahuanya dapat berupa pola data atau relasi antar data yang valid yang berarti tidak diketahui sebelumnya. Data mining juga merupakan gabungan sejumlah disiplin ilmu komputer yang didefinisikan sebagai proses penemuan pola-pola baru dari kumpulan-kumpulan data yang sangat besar, meliputi metode metode yang merupakan irisan dari artificial intelligence, machine learning, statistics dan databases system (Suyanto, 2017).

\subsection{Klasifikasi}

Klasifikasi merupakan suatu proses menemukan kumpulan pola atau fungsi yang mendeskripsikan serta memisahkan kelas data yang satu dengan yang lainnya untuk menyatakan objek tersebut masuk pada kategori tertentu yang sudah ditentukan. Klasifikasi adalah bentuk analisis data yang mengekstrak model yang menggambarkan kelas data. Klasifikasi data terdiri dari 2 langkah proses. Pertama adalah learning (fase training), dimana algoritma klasifikasi dibuat untuk menganalisa data training lalu direpresentasikan dalam bentuk rule klasifikasi. Proses kedua adalah klasifikasi, dimana data tes digunakan untuk memperkirakan akurasi dari rule klasifikasi. (J. Han, 2012).

\subsection{Normalisasi}

Normalization atau normalisasi adalah proses membuat beberapa variable memiliki rentang nilai yang sama, tidak ada yang terlalu besar dan terlalu kecil dimana sebuah atribut numerik diskalakan dalam range yang lebih kecil seperti -1.0 sampai 1.0 , atau 0.0 sampai 1.0. Agar semua fitur menjadi sama ketika menghitung jarak, fitur harus memiliki rentang nilai yang sama. Ini hanya dapat dicapai melalui normalisasi. (Hartanto Junaedi dkk, 2011).

\subsection{Algoritma K-Nearest Neighbor}

Algoritma K-Nearest Neighbor (K-NN) adalah sebuah metode untuk melakukan klasifikasi terhadap objek berdasarkan data pembelajaran yang jaraknya paling dekat dengan objek tersebut. K-Nearest Neighbor berdasarkan konsep 'learning by analogy'. Data learning dideskripsikan dengan atribut numerik n-dimensi. Tiap data learning merepresentasikan sebuah titik, yang ditandai dengan $\mathrm{c}$, dalam ruang $\mathrm{n}$ dimensi. Jika sebuah data query yang labelnya tidak diketahui diinputkan, maka K-Nearest Neighbor akan mencari $\mathrm{k}$ buah data learning yang jaraknya paling dekat dengan data query dalam ruang n-dimensi. (Mohammad Kafil, 2019).

Berikut ini adalah langkah-langkah dalam metode KNN :

1. Tentukan nilai parameter $\mathrm{K}$ (jumlah tetangga terdekat yang akan digunakan).

2. Hitung jarak antara data uji dengan setiap data latih. Beberapa metode yang digunakan adalah Euclidean Distance. Kelebihan metode Euclidean Distance adalah tingkat identifikasi kemiripan (similarity) lebih tinggi dibandingkan metode yang lain. (Tiskadewi, 2017)

Eucliedean distance menggunakan rumus dibawah ini :

$\mathrm{di}=\sqrt{\sum_{i=1\left(x_{2 i-x_{1 i}}^{p}\right)}^{2} \ldots \ldots \ldots \ldots \ldots . . \text { Persamaan } 2.1}$

Dimana :

$\mathrm{X} 1 i=$ sampel data

$\mathrm{X} 2 i=$ data pengujian

$i=$ index variable data

$\mathrm{di}=$ jarak

$\mathrm{p}=$ dimensi data

3. Urutkan hasil perhitungan jarak mulai dari yang terkecil (ascending).

4. 4. Ambil kelompok jarak terkecil sesuai dengan nilai parameter K yang sudah ditentukan.

5. Ambil hasil kategori mayoritas dari pengelompokan tadi.

\section{METODE PENELITIAN}

\subsection{Blok Diagram Sistem}

Blok diagram adalah diagram dari suatu sistem, di mana bagian utama dan fungsi yang diwakili oleh blok dihubungkan dengan menggunakan garis, yang menunjukkan hubungan dari blok. Proses kerja pada pengelompokan data mebel menggunakan metode KNearest Neighbor ditunjukan pada Gambar 1 


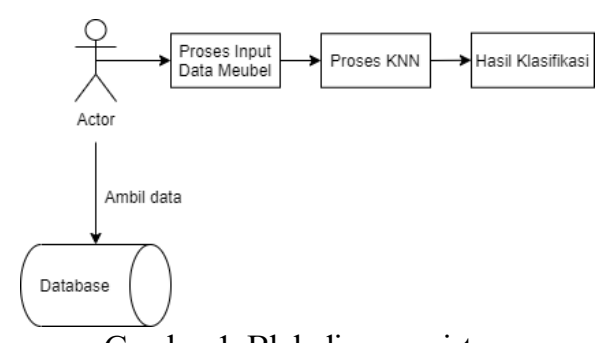

Gambar 1. Blok diagram sistem

\subsection{Flowchart Sistem}

Flowchart sistem ini menjelaskan proses berjalananya aplikasi seperti ditunjukkan pada Gambar 2

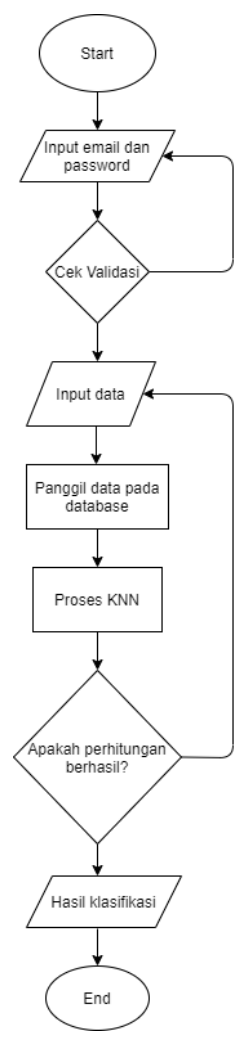

Gambar 2. Flowchart Sistem

Berdasarkan flowchart pada Gambar 3, flowchart sistem menjelaskan alur dari sistem yang dibuat. Mulai dari melakukan login dengan menginputkan username dan password, login akan dicek dahulu apakah username dan password yang diinputkan sudah benar. Jika benar maka admin akan akan masuk ke halaman menu admin, namum jika salah admin akan tetap di halaman login. Pada halaman menu admin, admin dapat melakukan kelola data barang mebel. Kemudian harus input memanggil data lama dan juga data baru untuk dibandingkan dengan menggunakan metode K-Nearest Neighbor untuk mendapatkan nilai klasifikasi. Proses terakhir adalah data klasifikasi sudah didapatkan maka proses telah selesai dan jika data tidak berhasil didapatkan maka proses akan diulang kembali pada input data.

\subsection{Flowchart Metode}

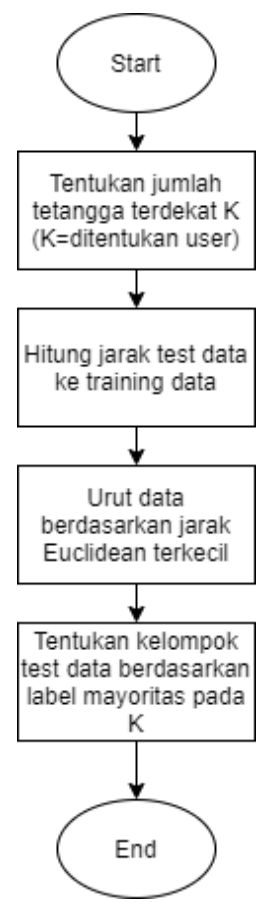

Gambar 3. Flowchart Metode

Pada Gambar 3. Flowchart metode menjelaskan tentang alur dari metode K-Nearest Neighbor. Alur metode dimulai dari melakukan input data sesuai atribut yang digunakan. Menentukan jumlah tetangga terdekat $\mathrm{K}$ yang ditentukan sendiri oleh user. Kemudian menghitung jarak nilai atribut pada setiap atribut training, data training berbentuk array, setelah menghitung jarak nilai atribut maka akan dilanjutkan dengan mensorting hasil jarak berdasarkan nilai yang paling rendah. Kemudian menghitung jumlah nilai yang paling banyak keluar dan hasil klasifikasi telah keluar. Langkah terakhir adalah menghitung tingkat akurasi dari hasil klasifikasi, dengan cara menghitung jumlah record uji yang kelasnya diklasifikasi secara tepat.

\section{HASIL DAN PEMBAHASAN}

\subsection{Halaman Login}

Merupakan form login yang hanya diberi akses oleh admin untuk mengelola sistem klasifikasi data produk mebel. Admin memasukkan username dan password.

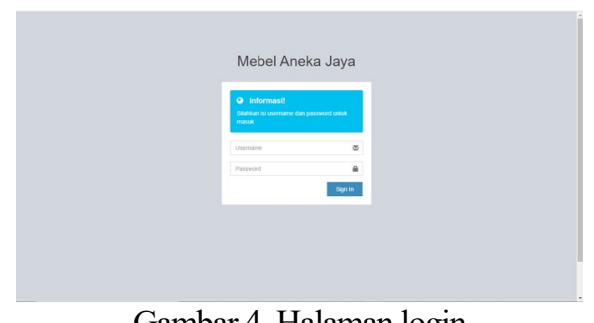

Gambar 4. Halaman login 


\subsection{Halaman home}

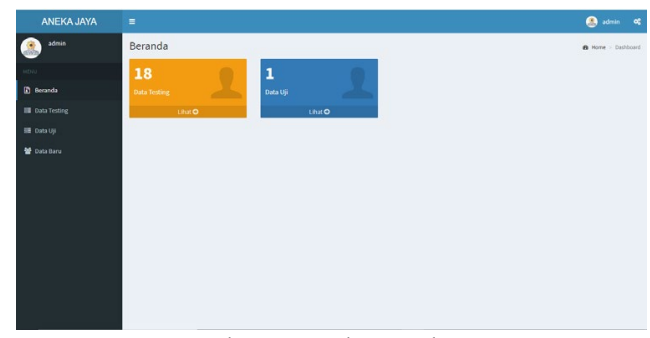

Gambar 5. Halaman home

Gambar 5 terdapat beranda yang menampilkan jumlah data training atau data latih dan data testing atau data uji.

\subsection{Halaman Data Training}

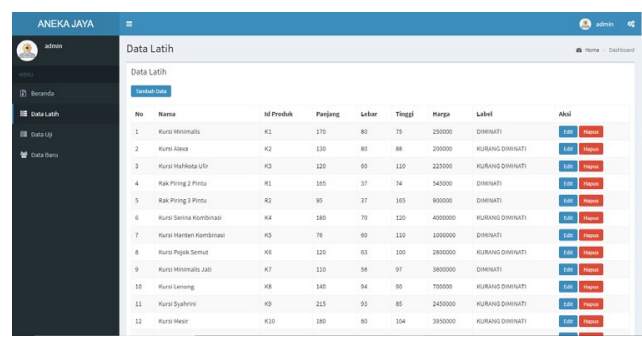

Gambar 6. Halaman data latih

Pada gambar 6 terdapat button tambah data, edit data dan hapus data. Data yang ditampilkan berupa nama produk, id produk, panjang, lebar, tinggi, harga dan label apakah produk mebel diminati atau kurang diminati.

\subsection{Halaman Data Uji}

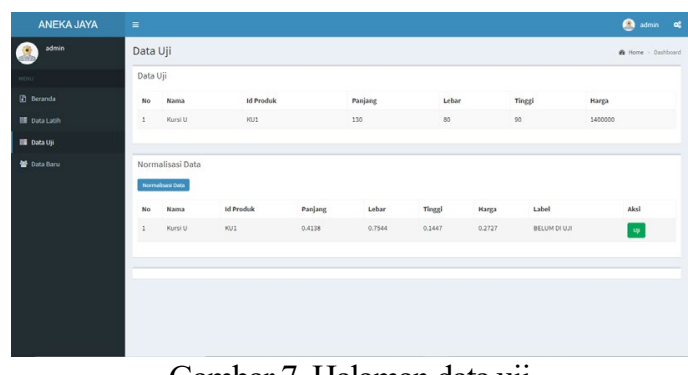

Gambar 7. Halaman data uji

Pada gambar 7 terdapat tampilan data uji yang muncul dan tampilan untuk menormalisasi data uji. Kemudian terdapat button untuk melakukan uji klasifikasi data produk mebel baru.

\subsection{Halaman Data Management}

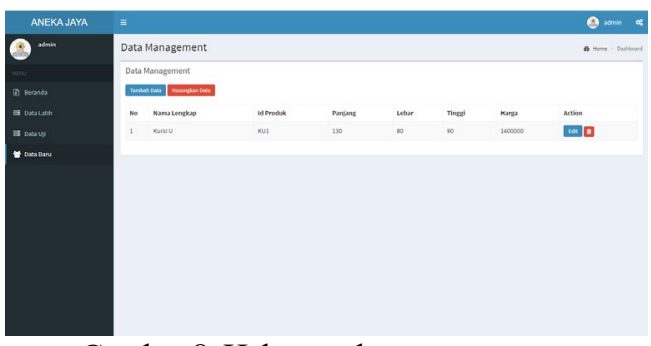

Gambar 8. Halaman data management

Pada gambar 8 merupakan tampilan untuk menambahkan data latih atau data training. Pada data training terdapat atribut berupa nama produk, id produk, panjang, lebar, tinggi, lebar, harga dan label apakah produk diminati atau kurang diminati.

\subsection{Pengujian black box}

Pengujian fungsional sistem dilakukan untuk menguji fitur-fitur yang ada pada klasifikasi data produk mebel aneka jaya menggunakan metode K-Nearest Neighbor berbasis web. Hasil pengujian fungsional sistem ditunjukan dalam Tabel 1

Tabel 1. Pengujian fungsional

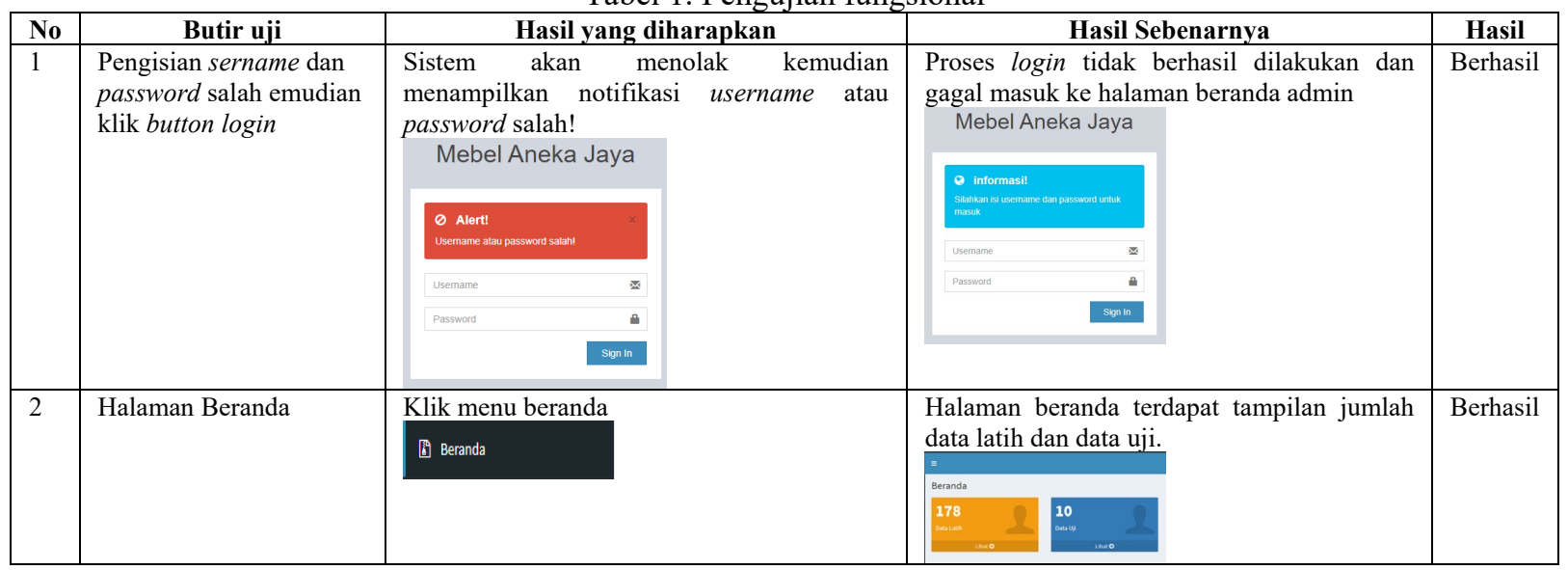




\begin{tabular}{|c|c|c|c|c|}
\hline 3 & Halaman Data Latih & $\begin{array}{l}\text { Klik menu data latih } \\
\text { Ea data Lath }\end{array}$ & $\begin{array}{l}\text { Data latih yang digunakan beserta hasil } \\
\text { normalisasi terverifikasi } \\
\text { dengan benar. }\end{array}$ & Berhasil \\
\hline 4 & Halaman Data Uji & 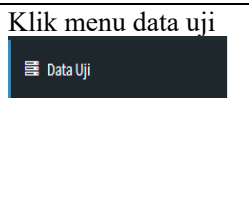 & $\begin{array}{l}\text { Data uji yang digunakan, hasil normalisasi } \\
\text { dan hasil pengujian } \\
\text { benar. }\end{array}$ & Berhasil \\
\hline 5 & Halaman Data Baru & $\begin{array}{l}\text { Klik menu data baru } \\
\text { * atabanu }\end{array}$ & $\begin{array}{l}\text { Data uji baru terverifikasi dengan benar dan } \\
\text { data masuk ke halaman data uji }\end{array}$ & Berhasil \\
\hline 6 & Cetak Laporan & $\begin{array}{l}\text { Klik cetak laporan } \\
\text { Cetak Laporan }\end{array}$ & $\begin{array}{l}\text { Hasil cetak laporan berdasarkan jarak } \\
\text { tetangga terdekat yang telah ditentukan } \\
\\
=\end{array}$ & Berhasil \\
\hline
\end{tabular}

\subsection{Pengujian Akurasi}

Tabel 2. pengujian akurasi

\begin{tabular}{|c|c|}
\hline TP (True Positif) & FP (False Positif) \\
\hline 8 & 2 \\
\hline FN (False Negatif) & TN (True Negatif) \\
\hline 0 & 0 \\
\hline
\end{tabular}

$$
\begin{aligned}
& \text { Accruracy }=\frac{T P+T N}{T P+T N+F P+F N} \\
& =\frac{8+0}{8+0+2+0} \\
& =0.8 * 100 \% \\
& =80 \%
\end{aligned}
$$

Kesimpulan perhitungan diatas didapatkan yaitu TP data benar yang terklasifikasikan menjadi data benar sebesar 8, nilai FP yaitu data terklasifikasi salah sebesar 2, nilai FN data salah tidak terklasifikasi salah sebesar 0 dan nilai TN adalah data yang tidak diklasifikasikan benar sebesar 0 , sehingga menghasilkan nilai Accuracy sebesar 80\%

\subsection{Pengujian Non-fungsional}

Pengujian Non-fungsional merupakan pengujian yang melakukan verifikasi pada kebutuhan nonfungsional seperti performa dan kegunaan sebuah aplikasi. Non-functional testing lebih kepada meningkatkan kualitas sebuah aplikasi atau website. Kualitas yang dimaksud yaitu berupa Waktu, Akurasi, Stabilitas, Kebenaran dan Durability di berbagai macam keadaan. Sebagai contoh: Loading halaman utama/dashboard hanya 5 detik setelah berhasil login.

Pada bagian pengujian non-fungsional ini, peneliti menggunakan pengujian stress testing yang digunakan untuk menguji stabilitas dan kemampuan sistem menerima traffic yang tinggi. Dikarenakan pengujian stress testing ini memiliki beberapa manfaat yaitu, menentukan batas, disaat sistem atau perangkat keras atau perangkat lunak mengalami down dan memeriksa apakah sistem yang digunakan memiliki error management yang baik atau tidak saat traffic tinggi dan server down. Untuk melakukan stress testing pada penelitian ini, peneliti menggunakan Apache Benchmark (AB). Apache benchmark merupakan sebuah tool untuk mengukur performance apache, dengen melihat kapabilitas apache untuk melayani request dari client.

Parameter yang terdapat pada apache benchmark dalam perintah yang digunakan adalah sebagai berikut:

-c = menyatakan jumlah request akses yang dilakukan oleh user dalam waktu bersamaan.

$-\mathrm{n}=$ menyatakan jumlah koneksi yang dibuat ke server tujuan.

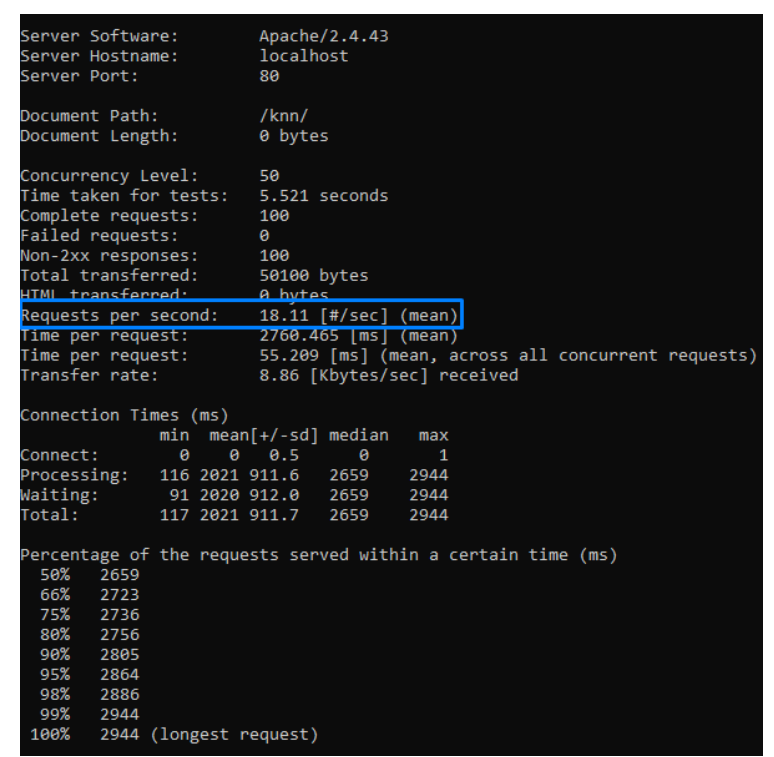

Gambar 9. stress testing 
Hasil pengujian adalah dilakukan dengan jumlah koneksi (-n) ke server anekajayamebel sejumlah 100 dan jumlah request (-c) akses sejumlah 50. Hasil pengujian dengan menggunakan apache benchmark, bahwa server mampu melayani request sebesar 18.11 per detik.

\subsection{Pengujian Browser}

Hasil pengujian aplikasi dengan menggunakan 2 browser yang berbeda, semua tampilan dan fungsi aplikasi dapat berjalan $100 \%$ pada 2 browser yaitu Opera versi 76.0.4017.177 dan Google Chrome versi 91.0.4472.106. Berikut adalah tabel hasil pengujian dari pembuatan aplikasi menggunakan dua browser yang ditunjukkan pada Tabel 3

Tabel 3. Pengujian browser

\begin{tabular}{|c|l|c|c|}
\hline No & Fungsi Yang Diuji & Chrome & Opera \\
\hline 1 & Login & $\sqrt{ }$ & $\sqrt{ }$ \\
\hline 2 & Halaman Beranda & $\sqrt{ }$ & $\sqrt{ }$ \\
\hline 3 & Halaman Data Latih & $\sqrt{ }$ & $\sqrt{ }$ \\
\hline & $\begin{array}{l}\text { a. Tambah Data } \\
\text { Latih }\end{array}$ & $\sqrt{ }$ & $\sqrt{ }$ \\
\hline & b. Edit Data Latih & $\sqrt{ }$ & $\sqrt{ }$ \\
\hline & c. Hapus Data Latih & $\sqrt{ }$ & $\sqrt{ }$ \\
\hline 4 & Halaman Data Uji & $\sqrt{ }$ & $\sqrt{ }$ \\
\hline 5 & Halaman Data Baru & $\sqrt{ }$ & $\sqrt{ }$ \\
\hline & $\begin{array}{l}\text { a. Tambah Data Uji } \\
\text { Baru }\end{array}$ & $\sqrt{ }$ & $\sqrt{ }$ \\
\hline & $\begin{array}{l}\text { b. Edit Data Uji } \\
\text { Baru }\end{array}$ & $\sqrt{ }$ & $\sqrt{ }$ \\
\hline 6 & B. Hapus Data Uji & $\sqrt{ }$ & $\sqrt{ }$ \\
\hline 7 & Halaman Profil & $\sqrt{ }$ & $\sqrt{ }$ \\
\hline 8 & Logout & $\sqrt{ }$ & $\sqrt{ }$ \\
\hline
\end{tabular}

\subsection{Pengujian User}

Pengujian user bertujuan untuk mengetahui apakah sistem sudah berjalan dengan baik atau belum. Kuesioner berisi 5 pertanyaan tentang aplikasi. Dalam menentukan hasil persentase kuesioner.

Berdasarkan hasil dari pengisian kuesioner yang didapatkan penulis dari responden dan dihitung jumlah keseluruhannya mendapatkan persentase hasil seperti berikut, dapat dilihat pada Tabel 4 .

Tabel 4. Pengujian User

\begin{tabular}{|c|c|c|c|c|}
\hline \multirow[b]{2}{*}{ No } & \multirow[b]{2}{*}{ Pernyataan } & \multicolumn{3}{|c|}{ Jawaban } \\
\hline & & $\begin{array}{l}\text { Sangat } \\
\text { Setuju }\end{array}$ & Setuju & $\begin{array}{c}\text { Kurang } \\
\text { Setuju }\end{array}$ \\
\hline 1. & $\begin{array}{l}\text { Tampilan user interface } \\
\text { terlihat menarik }\end{array}$ & & & Iya \\
\hline 2. & $\begin{array}{l}\text { Fitur yang ada berfungsi } \\
\text { dengan baik }\end{array}$ & Iya & & \\
\hline 3. & $\begin{array}{l}\text { Klasifikasi data produk } \\
\text { mebel mudah digunakan }\end{array}$ & & Iya & \\
\hline 4. & $\begin{array}{l}\text { Informasi yang ada mudah } \\
\text { dimengerti }\end{array}$ & Iya & & \\
\hline 5. & $\begin{array}{l}\text { Website dapat membantu } \\
\text { pemilik toko dalam } \\
\text { mengklasifikasikan }\end{array}$ & Iya & & \\
\hline
\end{tabular}

\subsection{Pengujian Metode}

1. Total data yang digunakan berjumlah 188 data dimana 178 data latih dan 10 data uji. Untuk contoh yang digunakan persiapkan 178 data latih dan 1 data uji. Atribut yang digunakan berupa nama produk, panjang, lebar, tinggi dan harga.

2. Melakukan normalisasi data

Dikarenakan terdapat perbedaan pada nilai atribut panjang, lebar dan tinggi terhadap harga maka diperlukanlah normalisasi pada data latih dan uji.

Tabel 5. Normalisasi data latih

\begin{tabular}{|l|l|l|l|l|l|}
\hline No & Nama & Panjang & Lebar & Tinggi & Harga \\
\hline 1. & Kursi Alexa & 0.52356 & 0.29412 & 0.35922 & 0.00873 \\
\hline 2. & Kursi Lenong & 0.57592 & 0.37647 & 0.36893 & 0.05423 \\
\hline 3. & $\begin{array}{l}\text { Beanbag } \\
\text { Cozy Pizza } \\
\text { Leather }\end{array}$ & 0.4712 & 0.29412 & 0.32039 & 0.03958 \\
\hline 4. & $\begin{array}{l}\text { Meja Makan } \\
\text { Stella }\end{array}$ & 0.62827 & 0.35294 & 0.29612 & 0.13238 \\
\hline 5. & $\begin{array}{l}\text { Sofa } \\
\text { Dudukan } \\
\text { Bran }\end{array}$ & 0.61257 & 0.24706 & 0.3301 & 0.18151 \\
\hline
\end{tabular}

Tabel 6. Normalisas data uji

\begin{tabular}{|c|c|c|c|c|c|}
\hline No & Nama & Panjang & Lebar & Tinggi & Harga \\
\hline 1 & Kursi U & 0.52356 & 0.29412 & 0.36893 & 0.11791 \\
\hline
\end{tabular}

3. Mencari nilai jarak dan mayoritas $\mathrm{K}$

Dimana nilai K ditentukan sendiri. Nilai K yang digunakan adalah 5 , terdapat 3 nilai $\mathrm{K}$ yang kurang diminati dan 2 nilai $\mathrm{K}$ yang masuk kategori diminati. Karena nilai mayoritas yang paling banyak berupa kurang diminati maka kesimpulan akhir data kursi $\mathrm{U}$ merupakan data yang kurang diminati.

Penjelasan klasifikasi berupa

$1=$ Diminati

$0=$ Kurang diminati

Tabel 7. Nilai jarak perhitungan manual

\begin{tabular}{|c|l|l|}
\hline Label & \multicolumn{1}{|c|}{ Nama } & \multicolumn{1}{c|}{ Jarak } \\
\hline 1 & Beanbag Cozy Pizza Leather & 0.10599198 \\
\hline 0 & Kursi Alexa & 0.10961106 \\
\hline 0 & Kursi Lenong & 0.1165306 \\
\hline 0 & Sofa Dudukan Bran & 0.12525677 \\
\hline 1 & Meja Makan Stella & 0.1411956 \\
\hline
\end{tabular}

Tabel 8. Pengujian persentase error

\begin{tabular}{|c|l|l|c|c|}
\hline Label & \multicolumn{1}{|c|}{ Nama } & \multicolumn{1}{|c|}{ Jarak } & Manual & Error \\
\hline 1 & $\begin{array}{l}\text { Beanbag Cozy Pizza } \\
\text { Leather }\end{array}$ & 0.10599198 & 0.10597 & $1.0 \%$ \\
\hline 0 & Kursi Alexa & 0.10961106 & 0.10963 & $0.9 \%$ \\
\hline 0 & Kursi Lenong & 0.1165306 & 0.11655 & $0.9 \%$ \\
\hline 0 & Sofa Dudukan Bran & 0.12525677 & 0.12522 & $1.0 \%$ \\
\hline 1 & Meja Makan Stella & 0.1411956 & 0.14117 & $1.0 \%$ \\
\hline
\end{tabular}

Dari hasil perbandingan diatas, dapat diketahui bahwa hasil perhitungan antara manual dengan Ms. Excel dengan perhitungan di sistem yang telah dibuat terdapat persentase error berkisar sampai 1.0\%. 


\section{KESIMPULAN DAN SARAN}

\subsection{Kesimpulan}

Kesimpulan yang dapat diuraikan dari hasil pembuatan klasifikasi data produk mebel aneka jaya menggunakan metode K-Nearest Neighbor berbasis web yaitu :

1. Klasifikasi data produk mebel aneka jaya menggunakan metode K-Nearest Neighbor berbasis web ini berhasil membantu dalam mengklasifikasikan data produk mebel baru.

2. Berdasarkan hasil pengujian fungsionalitas pada Klasifikasi data produk mebel aneka jaya menggunakan metode K-Nearest Neighbor berbasis web dapat dijalankan dengan baik pada browser web.

2. Berdasarkan hasil pengujian aplikasi dengan menggunakan 2 browser yang berbeda, semua tampilan dan fungsi aplikasi dapat berjalan $100 \%$ pada 2 browser yaitu, Opera dan Google Chrome.

3. Kesimpulan perhitungan pada pengujian akurasi yang didapatkan yaitu TP data benar yang terklasifikasikan menjadi data benar sebesar 8 , nilai FP yaitu data terklasifikasi salah sebesar 2 , nilai FN data salah tidak terklasifikasi salah sebesar 0 dan nilai $\mathrm{TN}$ adalah data yang tidak diklasifikasikan benar sebesar 0 , sehingga menghasilkan nilai Accuracy sebesar 80\%.

\subsection{Saran}

Berdasarkan penelitian yang telah dilakukan, maka penulis dapat memberikan saran-saran untuk pengembangan selanjutnya antar lain :

1. K-Nearest Neighbor bukan satu-satunya metode yang dapat digunakan untuk mengklasifikasikan direkomendasikan untuk mencoba menggunakan metode yang lain untuk membandingkan metode manakah yang lebih efektif.

2. Diharapkan sistem dapat dikembangkan lagi berbasis mobile/ios.

\section{DAFTAR PUSTAKA}

[1] Andrean Pungky (2019). Penerapan Metode KNN Untuk Memklasifikasi Hasil Pertanian
Kabupaten Malang. JATI (Jurnal Mahasiswa Teknik Informatika)

[2] Budi. (2018). Data Mining dan Big Data Analytics. Yogyakarta. Penebar Media Pustaka.

[3] Deva Gautama, Andrea (2019). Analisis Kualitas Hasil Panen Tembakau Menggunakan K-Nearest Neighbors Berbasis Web. JATI (Jurnal Mahasiswa Teknik Informatika) Vol. 3 No. 2, September 2019

[4] J. Han, M. K. (2012). Data Mining Concepts and Techniques 3rd Edition. USA: Morgan Kauffman.

[5] Junaedi, Hartanto, Herman Budianto, Indra Maryati dan Yuliana Melani (2011). Data Transformation Pada Data Mining, Surabaya. Prosiding Konferensi Nasional "Inovasi dalam Desain dan Teknologi” - IDeaTech 2011 ISSN: 2089-1121

[6] Karmila, Desi dan Depi Rusda (2019). EMarketplace Penjualan dan Pemasaran Barang Furniture Pada Toko Mebel Menggunakan PHP dan MYSQL Server. Jakarta. Jurnal Penelitian Dosen Fikom (UNDA) Vol.10 No.1 2019

[7] M Ja'far Sodiq (2020). Perbandingan Metode Naïve Bayes dan K-Nearest Neighbor Pada Klasifikasi Kualitas Udara Di DKI Jakarta. Jurnal University of Technology Yogyakarta

[8] Mohammad Kafil (2019). Penerapan Metode KNearest Neighbors Untuk Klasifikasi Penjualan Berbasis Web Pada Boutiq Deavole Bondowoso. JATI (Jurnal Mahasiswa Teknik Informatika)

[9] Setiawan Farhan (2018). Penerapan Metode KNearest Neighbors Untuk Mengklasifikasi Predikat Prestasi Akademik Santri Taman Pendidikan Al-Qur'an (TPQ) Al-Izzah Sidoarjo. JATI (Jurnal Mahasiswa Teknik Informatika)

[10] Suyanto. (2017). Data Mining Untuk Klasifikasi dan Klasterisasi Data. Bandung. Informatika.

[11] Tafyani Yusuf Prahudaya, A. H. (2017). Metode Klasifikasi Mutu Jambu Biji Menggunakan KNN Berdasarkan Fitur Warna Dan Tekstur. Jurnal Teknosains UGM

[12] Tiskadewi, Nirna (2017) Identifikasi Citra Iris Mata Dengan Metode KNN (K-Nearest Neighbor). Yogyakarta. STMIK AKAKOM. 